\title{
Coordinated approaches for studying long-term ecosystem responses to global change
}

\author{
Marcelo Sternberg • Dan Yakir
}

Received: 9 January 2015 / Accepted: 13 January 2015 / Published online: 13 February 2015

(C) Springer-Verlag Berlin Heidelberg 2015

\section{Introduction}

The rapidly-growing world population, over-exploitation of natural resources, climate change and land-use changes stimulate ecological research at all scales. Within this complex reality, ecological research should aim to project future ecosystem states and processes over time scales of decades and centuries, and spatially from the plot size to the global scale. However, do we know what are the best strategies and requirements for achieving this goal? It is increasingly recognized that there are three key components to planning global change research: First, a longterm research approach is needed to identify ecological and physiological adjustments, feedbacks and community-level changes that are relatively slow in pace. Too often, global change experiments are conducted across a wide range of managed and natural ecosystems, effectively characterizing short-term, rapid and small-scale processes (Fraser et al. 2013).

Second, research within the global change framework should combine monitoring, observational research, experimental manipulations and modeling. In particular, 'monitoring', such as of background climatic conditions, should

Communicated by Russell K. Monson.

M. Sternberg and D. Yakir contributed equally to the writing and the submission of this paper.

\section{Sternberg}

Department of Molecular Biology and Ecology of Plants, Faculty of Life Sciences, Tel-Aviv University, 69978 Tel-Aviv, Israel

\section{Yakir $(\bowtie)$}

Department of Earth and Planetary Sciences, Weizmann Institute of Science, 76100 Rehovot, Israel

e-mail:dan.yakir@weizmann.ac.il be distinguished from long-term 'experiments' that permit the formulation of theory on ecophysiological and population-to-community-scale processes, and testing of that theory. In other words, we must conceive and conduct experiments at large enough spatial and temporal scales, and with sufficient complexity to effectively define ecosystem-level feedbacks (Osmond et al. 2004; Baldocchi et al. 2001).

In more recent years, we have had access to processbased models that provide a useful means of generating hypotheses that can be tested by observations and experiential work. This permitted us to conduct experiments in silico: searching for optimal fits between theory and observations using models and maximum likelihood statistics. The models used for long-term assessments are usually built upon knowledge of ecosystem processes, and are often parameterized by short-term observations and experimental manipulation data. While this is still necessary, we can now go beyond this and use observations in ways other than for parameterization. Observations can now be used to test the adequacy for theory to represent processes, and provide validation through the assimilation of observations into the models with robust statistical tests of how well the theory permits the model to match the data (e.g., Zobitz et al. 2011; Leuzinger et al. 2011).

The third component of global change ecological studies refers to the large-scale context of the study and its environmental representation. This may require large facilities, extensive instrumentation, and a large spatial scale of observation (e.g., remote sensing; Sellers 1993), networks of research sites (e.g., Baldocchi et al. 2001), or largescale experimental systems (Gonzalez-Meler et al. 2014). While these requirements are often recognized individually, they are rarely discussed in an integrative manner within national or international research frameworks conducting global change research (Osmond et al. 2004). 
For many of the environmental issues we are facing, it is no longer possible for a single investigator, or even a team of investigators, to address large-scale ecological questions at the local or regional level (Luo et al. 2011). Coordinated distributed ecological experiments based on international collaboration are needed to address problems at regional and global scales in order to understand ecological patterns and processes, and to develop solutions for environmental management based on sound scientific data (Fraser et al. 2013).

The lack of integrative national-scale frameworks in Israel, and many other countries, led to the convening of a special "Batsheva de Rothschild seminar on coordinated approaches for studying long-term ecosystem responses to global change", in the fall of 2013, at the Ramat Hanadiv Nature Park in Israel (http://www.ramathanadiv.org.il/en). The seminar, supported by the Batsheva de Rothschild Fund of the Israel Academy of Sciences and Humanities, gathered international experts to discuss, and ultimately propose, a coordinated approach for a 'National Platform for Long-Term Global Change Research' in Israel. An Israeli program, in turn, can serve as a model for national-scale platforms, by virtue of Israel's location in a complex ecological junction spanning a relatively small spatial scale (Safriel 2010; Sternberg et al. 2014). This seminar generated a cluster of papers by seminar participants, their colleagues and researchers who could not attend, but are conducting research of a similar nature, which comprise the Special Section of the current issue of Oecologia.

\section{Features of the special section}

While spanning a wide diversity of topics, this cluster of articles also demonstrates that a relatively narrow range of perspectives related to key requirements and experimental approaches are used to carry out ecological research within the global change framework discussed above.

At the outset, Schimel and Keller (2015) present an overview of their experience gained in managing and evaluating large ecological and Earth science research projects. The authors discuss the increasing need for large-scale experiments to conduct global change studies of the terrestrial biosphere. But also highlight the less apparent reality that this requires significant adjustments on the part of ecologists towards the planning and management of large projects. These aspects must be considered as ecological research scales up from the traditional, single research group studies, to "big science" based on large infrastructures, such as control facilities (Gonzalez-Meler et al. 2014), FACE experiments (Ainsworth and Long 2005), multi-disciplinary supersites (e.g., Hari and Kulmala
2005), or networks such as LTER (Franklin et al. 1990), FLUXNET (Baldocchi et al. 2001), or multidisciplinary network of observatories, such as TERENO (Zacharias et al. 2011) or NEON (Keller et al. 2008).

Natural rainfall gradients provide a particularly useful opportunity to study the long-term effects of contrasting climatic regimes on ecosystem functioning (Dunne et al. 2004; Rustad 2008; Emmett et al. 2004), especially in arid and semi-arid settings such as in Israel (Sternberg et al. 2011; Golodets et al. 2013). Several studies in this Special Section further demonstrate the utility of experiments along climatic gradients both for assessing long-term changes (the 'space for time' approach; e.g., Hänel and Tielbörger 2015), and for examining a substantial range of climatic parameters, such as temperature and precipitation (e.g., Mowll et al. 2015; Knapp et al. 2015).

Almost all the papers in this Special Section highlight the importance of the long-term perspective, either combined with large spatial coverage along climatic gradients (e.g., Mowll et al. 2015; Knapp et al. 2015; Smith et al. 2015), as a basis to identify responses to key ecosystem drivers at smaller scales (e.g., Wertin et al. 2015), to detect recovery from disturbance and assess system resilience (e.g., Trahan et al. 2015), or to identify community-level responses (e.g., Hänel and Tielbörger 2015). Several of the papers have combined the use of studies across gradients with manipulation of plots to conduct experiments on processes and mechanisms driving ecosystem change. This lies at the heart of constructing and testing theories of how processes are linked to variable ecosystem states. This is also at the heart of how we will be able to improve models to represent process-state interactions, even beyond the currently observed system.

While naturally occurring geographical and climatic variations are shown to be useful, direct manipulation of key climatic parameters, such as temperature, precipitation, soil water availability, $\mathrm{CO}_{2}$ and nutrients, is ultimately needed to systematically quantify the effects of such parameters (e.g., Golodets et al. 2015; Knapp et al. 2015). Smith et al. (2015) highlight in particular the interactions of long-term perspective and resource manipulations: Chronic resource alterations result in a significant change in aboveground net primary production (ANPP) irrespective of ecosystem type, the length of the experiment, or the resource manipulated. However, the pattern of ecosystem response over time varies with ecosystem-type manipulation length, and plant community composition. As pointed out by Dorman et al. (2015), chronic resource limitation can also be the result of the interactions of competition intensity on limited rainfall.

Furthermore, the importance of considering multidimensional species effects on both chemical and physical ecosystem properties is highlighted by Sheffer et al. (2015), showing that man-made changes in the composition and 
configuration of plant communities may result in complex unpredicted consequences to ecosystem biogeochemistry.

In summary, the papers in this Special Section reveal how the wide range of ecological studies, addressing diverse research questions, ecosystems and vegetation types, all point to the key requirements that should be integrated in order to advanced ecological research in an era of global change. Identifying such common requirements and strategies should facilitate planning and coordination of national-, regional-, and ultimately globalscale ecological research, which was the central aim of the "Batsheva de Rothschild Seminar on coordinated approaches for studying long-term ecosystem responses to global change".

Author contribution statement D. Yakir and M. Sternberg jointly conceived this study and forum and jointly wrote the paper.

Acknowledgments The authors would like to thank the Batsheva de Rothschild Fund for supporting the seminar and to the Ramat Hanadiv Nature Park for hosting it.

\section{References}

Ainsworth EA, Long SP (2005) What have we learned from 15years of free-air CO2enrichment (FACE)? A meta-analyticreview of the responses of photosynthesis,canopy properties andplant production to rising $\mathrm{CO}_{2}$. New Phytol165:351-372

Baldocchi D, Falge E, Gu L, Olson R, Hollinger D, Running S, Anthoni P, Bernhofer CH, Davis K, Evans R, Fuentes J, Goldstein A, Katul G, Law B, Lee X, Malhi Y, Meyers T, Munger W, Oechel W, Paw UKT, Pilegaard K, Schmid HP, Valentini R, Verma S, Vesala T, Wilson K, Wofsy S (2001) FLUXNET: a new tool to study the temporal and spatial variability of ecosystemscale carbon dioxide, water vapor, and energy flux densities. Bull Am Meteorol Soc 82:2415-2434

Dorman M, Perevolotsky A, Sarris D, Svoray T (2015) The effect of rainfall and competition intensity on forest response to drought: lessons learned from a dry extreme. Oecologia (this issue)

Dunne JA, Saleska SR, Fischer ML, Harte J (2004) Integrating experimental and gradient methods in ecological climate change research. Ecology 86:904-916

Emmett BA, Beier C, Estiarte M et al (2004) The response of soil processes to climate change: results from manipulation studies of shrublands across an environmental gradient. Ecosystems 7:625-637

Franklin J, Bledsoe C, Callahan JT (1990) Contributions of the LTER program. Bioscience 40:7

Fraser LH, Henry AL, Carlyle H, White CN, Beierkuhnlein C, Cahill JF Jr, Casper B, Cleland E, Collins SL, Dukes JS, Knapp AK, Lind E, Long R, Luo Y, Reich PB, Smith MD, Sternberg M, Turkington R (2013) Coordinated Distributed Experiments: an emerging tool for testing global hypotheses in ecology and environmental science. Front Ecol Environ 11:147-155

Golodets C, Sternberg M, Kigel J, Boeken B, Henkin Z, Seligman NG, Ungar EU (2013) From desert to Mediterranean rangelands: will increasing drought and inter-annual rainfall variability affect herbaceous annual primary productivity? Clim Change 119:785-798

Golodets C, Sternberg M, Kigel J, Boeken B, Henkin Z, Seligman N G, Ungar EU (2015) Climate change scenarios of biomass production along an aridity gradient: vulnerability increases with aridity. Oecologia (this issue)

Gonzalez-Meler MA, Rucks JS, Aubanell G (2014) Mechanistic insights on the responses of plant and ecosystem gas exchange to global environmental change: lessons from Biosphere 2. Plant Sci 226:14-21

Hänel S, Tielbörger K (2015) Phenotypic response of plants to simulated climate change in a long-term rain manipulation experiment-a multi-species study. Oecologia (this issue)

Hari P, Kulmala M (2005) Station for measuring ecosystem-atmosphere relations. Boreal Environ Res 10:315-322

Keller M, Schimel D, Hargrove WW, Hoffman FM (2008) A continental strategy for the National Ecological Observatory Network. Front Ecol Environ 6:282-284

Knapp AK, Carroll CJW, Denton EM, La Pierre KJ, Collins SL, Smith MD (2015) Differential sensitivity to regional-scale drought in six central U.S. grasslands. Oecologia (this issue)

Leuzinger S, Luo Y, Beier C, Dieleman W, Vicca S, Körner C (2011) Do global change experiments overestimate impacts on terrestrial ecosystems? Trends Ecol Evol 26:236-241

Luo Y, Melillo J, Niu S et al (2011) Coordinated approaches to quantify long-term ecosystem dynamics in response to global change. Glob Change Biol 17:843-854

Mowll W, Blumenthal DM, Cherwin K, Smith A, Symstad AJ, Vermeire LT, Collins SL, Smith MD, Knapp AK (2015) Climatic controls of aboveground net primary production in semi-arid grasslands along a latitudinal gradient portend low sensitivity to warming. Oecologia (this issue)

Osmond B, Ananyev G, Berry J, Langdon C, Kolber Z, Gunghui L, Monson R, Nichol C, Rascher U, Schurr U et al (2004) Changing the way we think about global research: scaling up in experimental ecosystem science. Glob Change Biol 10:393-407

Rustad LE (2008) The response of terrestrial ecosystems to global climate change: towards an integrated approach. Sci Total Environ 404:222-235

Safriel U (2010) Israel's National Biodiversity Plan. Ministry of Environmental Protection http://www.cbd.int/iyb/doc/celebrations/ iyb-israel-sviva-plan-en.pdf

Schimel DS, Keller M (2015) Hypotheses, measurements and research writ large: meeting the challenges of global ecology. Oecologia (this issue)

Sellers P, Schimel DS (1993) Remote sensing of the land biosphere and 576 biogeochemistry in the EOS era: science priorities, methods and implementation-577 EOS land biosphere and biogeochemical cycles panels. Glob Planet Change 578(7):279-297

Sheffer E, Canham CD, Kigel J, Perevolotsky A (2015) Countervailing effects on pine and oak leaf litter decomposition in humanaltered Mediterranean ecosystems. Oecologia (this issue)

Smith MD, La Pierre KJ, Collins SL, Knapp AK, Gross KL, Barrett JE, Frey SD, Gough L, Miller RJ, Morris JT, Rustad LE, Yarie J (2015) Global environmental change and the nature of aboveground net primary productivity responses: insights from longterm experiments. Oecologia (this issue)

Sternberg M, Holzapfel C, Tielbörger K, Sarah P, Kigel J, Lavee H, Fleischer A, Jeltsch F, Köchy M (2011) The use and misuse of climatic gradients for evaluating climate impact on dryland ecosystems - an example for the solution of conceptual problems. In: Blanco J, Kheradmand H (ed) Climate change-geophysical foundations and ecological effects. InTech, Rijek, pp 361-374

Sternberg M, Gabay O, Angel D, Barneah O, Gafny S, Gasith A, Grünzweig JM, Hershkovitz Y, Israel A, Milstein D, Rilov G, Steinberger Y, Zohary T (2014) Impacts of climate change on 
biodiversity in Israel-an expert assessment approach. Reg Environ Change. doi:10.1007/s10113-014-0675-Z

Talmon Y, Sternberg M, Grunzweig JM (2011) Impact of rainfall manipulations and biotic controls on soil respiration in Mediterranean and desert ecosystems along an aridity gradient. Glob Change Biol 17:1108-1118

Trahan NA, Dynes ED, Pugh E, Moore DJP, Monson RK (2015) Long-term observations on changes in soil biogeochemistry following disturbance by girdling and mountain pine beetles in subalpine forests. Oecologia (this issue)
Wertin TM, Reed SC, Belnap J (2015) Increasing temperatures have significant negative consequences for both $\mathrm{C} 3$ and $\mathrm{C} 4$ dryland plant species on the Colorado Plateau, USA. Oecologia (this issue)

Zacharias S et al (2011) A network of terrestrial environmental observatories in Germany. Vadose Zone J 10:955-973

Zobitz JM, Desai AR, Moore DJP, Chadwick MA (2011) A primer for data assimilation with ecological models using Markov Chain Monte Carlo (MCMC). Oecologia 167:599-611 